Atmos. Chem. Phys., 13, 9607-9621, 2013

www.atmos-chem-phys.net/13/9607/2013/

doi:10.5194/acp-13-9607-2013

(c) Author(s) 2013. CC Attribution 3.0 License.

\title{
The impact of emission and climate change on ozone in the United States under representative concentration pathways (RCPs)
}

\author{
Y. Gao ${ }^{1, *}$, J. S. Fu' ${ }^{1}$, J. B. Drake ${ }^{1}$, J.-F. Lamarque ${ }^{2}$, and Y. Liu ${ }^{3}$ \\ ${ }^{1}$ Department of Civil and Environmental Engineering, University of Tennessee, Knoxville, Tennessee, USA \\ ${ }^{2}$ Atmospheric Chemistry and Climate and Global Dynamics Divisions, National Center for Atmospheric Research, Boulder, \\ Colorado, USA \\ ${ }^{3}$ Rollins School of Public Health, Emory University, Atlanta, Georgia, USA \\ * now at: Atmospheric Science and Global Change Division, Pacific Northwest National Laboratory, Richland, Washington, \\ USA
}

Correspondence to: J. S. Fu (jsfu@utk.edu)

Received: 20 February 2013 - Published in Atmos. Chem. Phys. Discuss.: 26 April 2013

Revised: 25 July 2013 - Accepted: 16 August 2013 - Published: 27 September 2013

\begin{abstract}
Dynamical downscaling was applied in this study to link the global climate-chemistry model Community Atmosphere Model (CAM-Chem) with the regional models Weather Research and Forecasting (WRF) Model and Community Multi-scale Air Quality (CMAQ). Two representative concentration pathway (RCP) scenarios (RCP 4.5 and RCP $8.5)$ were used to evaluate the climate impact on ozone concentrations in the 2050s.

From the CAM-Chem global simulation results, ozone concentrations in the lower to mid-troposphere (surface to $\sim 300 \mathrm{hPa}$ ), from mid- to high latitudes in the Northern Hemisphere, decreases by the end of the 2050s (2057-2059) in RCP 4.5 compared to present (2001-2004), with the largest decrease of 4-10 ppbv occurring in the summer and the fall; and an increase as high as 10 ppbv in RCP 8.5 resulting from the increased methane emissions.

From the regional model CMAQ simulation results, under the RCP 4.5 scenario (2057-2059), in the summer when photochemical reactions are the most active, the large ozone precursor emissions reduction leads to the greatest decrease of downscaled surface ozone concentrations compared to present (2001-2004), ranging from 6 to 10 ppbv. However, a few major cities show ozone increases of 3 to $7 \mathrm{ppbv}$ due to weakened NO titration. Under the RCP 8.5 scenario, in winter, downscaled ozone concentrations increase across nearly the entire continental US in winter, ranging from 3 to $10 \mathrm{ppbv}$ due to increased methane emissions. More intense heat waves are projected to occur by the end of the
\end{abstract}

2050s in RCP 8.5 , leading to a 0.3 ppbv to 2.0 ppbv increase (statistically significant except in the Southeast) of the mean maximum daily $8 \mathrm{~h}$ daily average (MDA8) ozone in nine climate regions in the US. Moreover, the upper $95 \%$ limit of MDA8 increase reaches $0.4 \mathrm{ppbv}$ to $1.5 \mathrm{ppbv}$ in RCP 4.5 and $0.6 \mathrm{ppbv}$ to $3.2 \mathrm{ppbv}$ in RCP 8.5 . The magnitude differences of increase between RCP 4.5 and 8.5 also reflect that the increase of methane emissions may favor or strengthen the effect of heat waves.

\section{Introduction}

The Special Report on Emissions Scenarios (SRES; Nakicenovic and Swart, 2000) has been designed and the Coupled Model Intercomparison Project phase 3 (CMIP3) simulations have been conducted in support of the Intergovernmental Panel on Climate Change (IPCC) Fourth Assessment Report (Solomon et al., 2007). As a result, climate change under the SRES scenarios has been fully evaluated (Annan and Hargreaves, 2011; Meehl et al., 2005, 2007). Likewise, "representative concentration pathways" 1 " (RCPs, Moss et al., 2010) scenarios were designed and the CMIP Phase 5 (CMIP5) (Taylor et al., 2009, 2012) simulations were conducted to investigate the impact of greenhouse gases on climate change for the upcoming IPCC Fifth Assessment Report (AR5).

\footnotetext{
${ }^{1} \mathrm{http} / / / \mathrm{www}$. iiasa.ac.at/web-apps/tnt/RcpDb/dsd?Action= htmlpage $\{\backslash \&\}$ page $=$ about
} 
Recent comparisons and evaluations of climate between CMIP3 and CMIP5 models (Stroeve et al., 2012; Knutti and Sedlacek, 2013; Rogelj et al., 2012) have shown that climate change strongly impacts regional meteorology and air quality. Thus, researchers have performed sensitivity studies to investigate the effects of perturbations in climate on air quality, and these studies were recently reviewed and discussed by Jacob and Winner (2009) and Fiore et al. (2012). In order to further evaluate the relationships between atmospheric chemistry and climate change under RCP scenarios, and to support the IPCC AR5, the Atmospheric Chemistry and Climate Model Intercomparison Project (ACCMIP) (Lamarque et al., 2013) has been established and global chemistry models have resolutions of 1-2 degrees or more. Global chemistry models predict that by the end of 21 st century, tropospheric ozone will decrease under the RCP 2.6, RCP 4.5 and RCP 6.0 scenarios, and increase under the RCP 8.5 scenario (Lamarque et al., 2011a; Kawase et al., 2011; Young et al., 2013).

However, due to the coarse spatial resolutions, global climate/chemistry studies often lack useful local air quality information, which could be applied to policy strategies. Thus, a technique, called dynamical downscaling (Caldwell et al., 2009; Lam and Fu, 2009), is commonly used to link global and regional models. This is done by applying the initial and boundary conditions from global models to serve as drivers of regional models and results in high-resolution simulations. Dynamical downscaling has been widely used in evaluating regional air quality under the IPCC SRES scenarios.

Bell et al. (2007) found that under the IPCC SRES A2 climate scenario (spatial resolution of $36 \mathrm{~km}$, emissions kept at present levels), summer hourly ozone across 50 cities in the Eastern US was projected to increase by an average of $4.8 \mathrm{ppbv}$ with a maximum of $9.6 \mathrm{ppbv}$ by the $2050 \mathrm{~s}$. They also found that the mean number of days exceeding the maximum daily $8 \mathrm{~h}$ ozone (MDA8) regulatory standard increased by $68 \%$. While maintaining emissions at current levels and using a spatial resolution of $36 \mathrm{~km}$, Nolte et al. (2008) found an overall increase from 2 to $5 \mathrm{ppbv}$ in MDA8 in Texas and parts of the Eastern US under A1B scenario by the 2050s. By using a global chemistry model (Model for OZone And Related Chemical Tracers, MOZART) with a spatial resolution of $30 \mathrm{~km}$, Huang et al. (2008) found that the five-year summer mean ozone concentrations increase by $4 \%$ to $9 \%$ in most US regions in the 2050s with increased anthropogenic emissions under the A1FI scenario. In the Eastern US, Lam et al. (2011) found 2 to 5 ppbv increase of MDA8 in the 2050s compared to the 2000s, with climate change under A1B scenario while maintaining emissions at $2000 \mathrm{~s}$ level; a $\sim 5 \mathrm{ppbv}$ decrease under A1B scenario from the combined effect of climate change and emission reductions was found with spatial resolutions of $36 / 12 \mathrm{~km}$. It is worth noting that these different scenarios have different levels of ozone precursor emissions, including methane.
Until now, there were very limited applications of dynamical downscaling under the new RCP scenarios. Kelly et al. (2012) used a Unified Regional Air-quality Modelling System (AURAMS) on a $45 \mathrm{~km} \times 45 \mathrm{~km}$ resolution grid and found, under A2 climate and RCP 6.0 ozone precursor emissions, that ozone concentrations decrease for most of the US. The mixture of SRES climate and RCP emissions makes it difficult to classify this study as either an SRES or RCP scenario.

Another important issue is spatial resolution. High resolution $(12 \mathrm{~km})$ could produce a better representation of atmospheric circulation and topographic features, while $36 \mathrm{~km}$ is too coarse to resolve important regional details, particularly in mountainous areas (Mass et al., 2002; Caldwell et al., 2009). All these studies, including both SRES and RCPs, have spatial resolutions of $30 \mathrm{~km}$ or coarser (except Lam et al., 2011 applies $12 \mathrm{~km}$ in the Eastern US), which may not be able to well capture topography and climate details.

Under both SRES (Ganguly et al., 2009; Meehl and Tebaldi, 2004) and RCP (Gao et al., 2012; Meehl et al., 2011) scenarios, more intense heat waves were projected to occur in future climate conditions. Heat waves have been reported to increase ozone concentrations dramatically. During the first two weeks of August 2003, heat waves in the UK caused mean population-weighted ozone concentration to reach as high as $103 \mu \mathrm{g} \mathrm{m}^{-3}$, while ozone concentrations were only around $58 \mu \mathrm{g} \mathrm{m}^{-3}$ during the same period in 2002 (Stedman, 2004). During the heat waves in 2003 , Vieno et al. (2010) found that a temperature increase of $5{ }^{\circ} \mathrm{C}$ could lead to a surface ozone increase of up to $9 \mathrm{ppbv}$ at Writtle $(70 \mathrm{~km}$ northeast of London). Although heat waves have been widely investigated under future climate scenarios (Ganguly et al., 2009; Meehl and Tebaldi, 2004; Gao et al., 2012; Meehl et al., 2011), their impact on ozone concentrations have not attracted the same amount of attention.

Thus, to provide more reasonable high-resolution information, this study is the first assessment to apply the dynamical downscaling technique under the new RCP scenarios with a spatial resolution of $12 \mathrm{~km}$ by $12 \mathrm{~km}$ over the continental US region. This paper documents the downscaling methodology, investigates the tropospheric ozone changes under future climate conditions, and evaluates the impact of heat waves on ozone concentrations in the US.

\section{Model description and configuration}

This study involves both global and regional climatechemistry models. Global climate model the Community Earth System Model (CESM) version 1.0 was used to conduct global climate simulations. There are four major components in the CESM: the Community Atmosphere Model(CAM4) (Neale et al., 2010), the Community Land Model (CLM4) (Oleson, 2010), the Parallel Ocean Program version 2 (POP2) (Smith et al., 2010), and the Los Alamos 
National Laboratory Sea Ice Model, version 4 (CICE4) (Hunke and Lipscomb, 2008). The CESM was run with a spatial resolution of 0.9 (latitude) by 1.25 (longitude) degrees and 26 vertical layers with the model top at $\sim 3 \mathrm{hPa}$ (Neale et al., 2010).

The atmospheric chemistry integrated in the atmosphere component CAM4 in the CESM is referred to as the CAMChem. The descriptions and parameterizations have been discussed in detail by Lamarque et al. (2012). In summary, the major physics used in CAM4 include the ZhangMcFarlane deep convection scheme (Zhang and McFarlaneb, 1995), Hack shallow convection scheme (Hack et al., 2006) and Holtslag and Boville's (1993) planetary boundary layer process. The atmospheric chemistry was adapted from the Model for OZone And Related chemical Tracers (MOZART version 4) and bulk aerosol model was used in CAM-Chem (Emmons et al., 2010; Lamarque et al., 2005). The CAMChem has been widely used and evaluated on its representation of atmospheric chemistry in the atmosphere (Aghedo et al., 2011; Lamarque et al., 2011a, b, 2012; Lamarque and Solomon, 2010). The atmospheric chemistry is computed at the same resolution (horizontal and vertical) as the atmosphere model. In order for the performed simulations to be consistent with the simulations performed for CMIP5 (without chemistry; Taylor et al., 2009, 2012), the simulated chemical fields do not affect the simulated climate, eliminating the risk of generating a different climate than the original CESM simulations.

The regional climate model WRF 3.2.1 (Skamarock and Klemp, 2008) was used in the regional climate simulations. The configurations of WRF have been discussed by Gao et al. (2012), and the major physics options include the SingleMoment 6-class microphysical scheme (WSM6) (Hong and Lim, 2006), the new Kain-Fritsch convective parameterization (Kain, 2004), the Rapid Radiative Transfer Model for Global Climate Models (RRTMG) longwave and shortwave radiation (Iacono et al., 2008; Morcrette et al., 2008), the Mellor-Yamada-Janjic planetary boundary layer (PBL) scheme (Janjić, 1990; Mellor and Yamada, 1982), and the Noah land surface model (Chen and Dudhia, 2001). There are a total of 34 vertical layers with model top pressure at $50 \mathrm{hPa}$.

The latest version of regional chemistry model Community Multi-scale Air Quality (CMAQ) modeling system version 5.0 (Wong et al., 2012) was used for the regional air quality simulations. Since its first release in 1998, tremendous efforts have been made by the United States Environmental Protection Agency (US EPA) (Wong et al., 2012; Byun and Schere, 2006) and air quality modeling community to develop and improve the model. The CMAQ model has become a three dimensional comprehensive atmospheric chemistry and transport model, and has been widely used in air quality modeling community (Fu et al., 2012a, b; Huang et al., 2012; Wong et al., 2012; Nolte et al., 2008). The same model top pressure as WRF $(50 \mathrm{hPa})$, and 14 vertical layers were applied to take into account computational limitations. WRF outputs were processed by the Meteorology-Chemistry Interface Processor (MCIP) (Otte and Pleim, 2010) in order to be used as CMAQ inputs.

Figure 1 shows the regional WRF-CMAQ simulation domain with a spatial resolution of $12 \mathrm{~km}$ by $12 \mathrm{~km}$, and covers parts of Canada, Mexico, and the continental US. According to the National Climatic Data Center (NCDC) ${ }^{2}$, the continental US can be divided into nine climate regions, which are the major focus areas in this study.

In addition to historical simulations (1850-2005), a total of four RCP scenarios (2005-2100), including RCP 2.6, RCP 4.5, RCP 6.0 and RCP 8.5, have been designed for the CMIP5. Due to limited computational resources, RCP 4.5 and RCP 8.5 were selected for this study. The central purposes of the selection were to evaluate and compare the climate and air quality under a low-to-medium emission scenario (RCP 4.5, Smith and Wigley, 2006; Wise et al., 2009) and a fossil fuel intensive emission scenario (RCP 8.5, Riahi et al., 2007). CAM-Chem was used to conduct global simulations from 2001 to the end of the 21st century continuously. The evaluation of CAM-Chem has been fully documented by Lamarque et al. (2012) and its application to the RCP simulations is discussed in Lamarque et al. (2011a). After the global chemistry simulations, considering the computational limitations, a four-year period (2001-2004) and three-year period (2057-2059) were used to evaluate the impact of present climate and future climate on ozone air quality.

\section{Dynamical downscaling}

Dynamical downscaling is a technique that uses the outputs from global climate or chemistry models to provide the initial and boundary conditions for the regional models. In this study, three hourly global model outputs from CESM and CAM-Chem are used to provide the initial and boundary conditions for regional models WRF and CMAQ, simulations, respectively. WRF outputs are further used as the meteorological input for CMAQ. The detailed climate downscaling methodology from CESM to WRF has been described by Gao et al. (2012). Thus, only chemistry downscaling methodology was discussed in detail here. The chemistry downscaling process involves species mapping; and horizontal and vertical interpolations.

\subsection{Species mapping from CAM-Chem to CMAQ}

The first step for downscaling is to map the species in the global chemistry model CAM-Chem to the regional chemistry model CMAQ, listed in Table 1 (Emmons et al., 2010; Yarwood et al., 2005). During this process, most species can be mapped directly between these two models, except

\footnotetext{
${ }^{2} \mathrm{http}: / / \mathrm{www} \cdot n \mathrm{ndc}$.noaa.gov/temp-and-precip/ us-climate-regions.php
} 
Table 1. Mapping table between CAM-Chem and CMAQ.

\begin{tabular}{|c|c|c|}
\hline CAM-Chem species & Species Name & CMAQ species \\
\hline \multicolumn{3}{|l|}{ Gas Species } \\
\hline $\mathrm{O}_{3}$ & Ozone & $\mathrm{O}_{3}$ \\
\hline NO & Nitric oxide & NO \\
\hline $\mathrm{NO}_{2}$ & Nitrogen dioxide & $\mathrm{NO}_{2}$ \\
\hline $\mathrm{NO}_{3}$ & Nitrate radical & $\mathrm{NO}_{3}$ \\
\hline $\mathrm{HNO}_{3}$ & Nitric Acid & $\mathrm{HNO}_{3}$ \\
\hline $\mathrm{HO}_{2} \mathrm{NO}_{2}$ & Peroxynitric acid & PNA \\
\hline $\mathrm{N}_{2} \mathrm{O}_{5}$ & Dinitrogen pentoxide & $\mathrm{N}_{2} \mathrm{O}_{5}$ \\
\hline $\mathrm{OH}$ & Hydroxyl radical & $\mathrm{OH}$ \\
\hline $\mathrm{HO}_{2}$ & Hydroperoxyl radical & $\mathrm{HO}_{2}$ \\
\hline $\mathrm{HO}_{2}$ & Hydrogen Peroxide & $\mathrm{HO}_{2}$ \\
\hline $\mathrm{CO}$ & Carbon monoxide & $\mathrm{CO}$ \\
\hline $\mathrm{CH}_{3} \mathrm{OOH}$ & Methyl hydroperoxide & MEPX \\
\hline $\mathrm{CH}_{2} \mathrm{O}$ & Formaldehyde & FORM \\
\hline $\mathrm{C}_{2} \mathrm{H}_{4}$ & Ethene & ETH \\
\hline $\mathrm{CH}_{3} \mathrm{CHO}$ & Acetaldehyde & ALD2 \\
\hline $\mathrm{C}_{2} \mathrm{O}_{3}$ & Acetylperoxy radical & $\mathrm{C}_{2} \mathrm{O}_{3}$ \\
\hline PAN & Peroxyacetyl nitrate & PAN \\
\hline $\mathrm{CH}_{3} \mathrm{COCHO}$ & Methylglyoxal and other aromatic products & MGLY \\
\hline $\mathrm{ROOH}$ & Higher organic peroxide & $\mathrm{ROOH}$ \\
\hline ONIT & Organic nitrate & NTR \\
\hline ISOP & Isoprene & ISOP \\
\hline PAR & Paraffin carbon bond $(\mathrm{C}-\mathrm{C})$ & PAR \\
\hline OLE & Terminal olefin carbon bond $(\mathrm{R}-\mathrm{C}=\mathrm{C})$ & OLE \\
\hline TOLUENE & Toluene and other monoalkyl aromatics & TOL \\
\hline $\mathrm{SO}_{2}$ & Sulfur dioxide & $\mathrm{SO}_{2}$ \\
\hline $\mathrm{C}_{10} \mathrm{H}_{16}$ & Terpene & TERP \\
\hline $\mathrm{NH}_{3}$ & Ammonia & $\mathrm{NH}_{3}$ \\
\hline $\mathrm{CH}_{4}$ & Methane & $\mathrm{CH}_{4}$ \\
\hline $\mathrm{XO}_{2}$ & $\mathrm{NO}$ to $\mathrm{NO}_{2}$ conversion from alkylperoxy $\left(\mathrm{RO}_{2}\right)$ radical & $\mathrm{XO}_{2}$ \\
\hline $\mathrm{XO}_{2} \mathrm{~N}$ & NO to organic nitrate conversion from alkylperoxy $\left(\mathrm{RO}_{2}\right)$ radical & $\mathrm{XO}_{2} \mathrm{~N}$ \\
\hline ROR & Secondary alkoxy radical & ROR \\
\hline CL2 & Chlorine gas & CL2 \\
\hline HOCL & Hypochlorous acid & HOCL \\
\hline HCL & Hydrogen chloride & HCL \\
\hline \multicolumn{3}{|l|}{ Particulate Matters } \\
\hline $\mathrm{SO}_{4}$ & Sulfate & ASO4J \\
\hline $\mathrm{NH}_{4} \mathrm{NO}_{3}$ & Ammonium nitrate & $\mathrm{ANH} 4 \mathrm{~J}+\mathrm{ANO} 3 \mathrm{~J}$ \\
\hline $\mathrm{CB} 1+\mathrm{CB} 2$ & Black carbon, hydrophobic + hydrophillic & AECJ \\
\hline $\mathrm{OC} 1+\mathrm{OC} 2$ & Organic carbon, hydrophobic+hydrophillic & APOCJ \\
\hline SSLT1+SSLT2 & Sea salt, $0.1-0.5 \mu \mathrm{m}, 0.5-1.5 \mu \mathrm{m}$ & ANAJ/ACLJ \\
\hline SSLT3+SSLT4 & Sea salt, $1.5-5 \mu \mathrm{m}, 5-10 \mu \mathrm{m}$ & ANAK/ACLK \\
\hline
\end{tabular}

secondary organic aerosols (SOA). A bulk aerosol model was used in CAM-Chem (Lamarque et al., 2012); thus, only combined anthropogenic and biogenic SOA was generated. However, a more sophisticated aerosol scheme (AE6) was implemented in CMAQ 5.0 and includes 24 semi-volatile SOA and 7 nonvolatile SOA (Carlton et al., 2010). No universal ratios can be used to partition the combined anthropogenic and biogenic SOA to different SOA species. As suggested by Carlton et al. (2010), CMAQ simulations driven by the default relatively clean air initial and boundary conditions were conducted. Then the ratios among the SOA species were used to allocate each SOA species based on the combined SOA.

\subsection{Initial and boundary conditions}

For the downscaling process, CAM-Chem was used to provide the initial and boundary conditions for CMAQ. Initial conditions are needed only for the first time step while three 


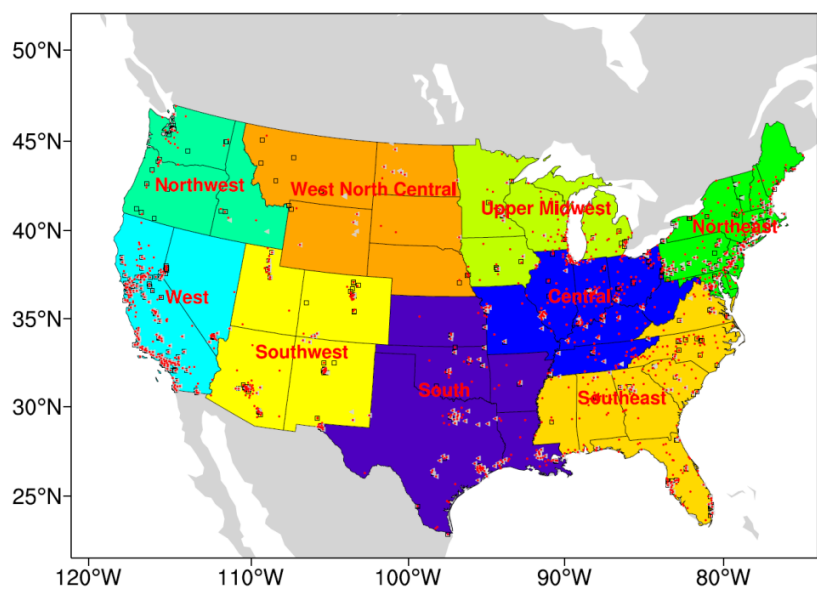

Fig. 1. $12 \mathrm{~km}$ by $12 \mathrm{~km}$ simulation domain with nine climate regions in the US. The red points $(\sim 1200)$, the gray triangles $(\sim 450)$ and black squares $(\sim 450)$ represent the observational sites of $\mathrm{O}_{3}, \mathrm{NO}_{2}$ and CO, respectively, obtained from Air Quality System (AQS, http: //www.epa.gov/ttn/airs/airsaqs/detaildata/downloadaqsdata.htm).

hourly boundary conditions were generated to achieve better diurnal representation.

It is important to keep the downscaled initial and boundary conditions consistent with the CAM-Chem outputs. Figure 2 shows the surface boundary conditions for the continental US domain used in CMAQ and the corresponding grids in CAM-Chem at the first hour on 1 July 2001 as an example. Due to the differences of spatial resolutions between CAMChem and CMAQ, the grid cells in CAM-Chem closest to the CMAQ domain were used. Figure $2 \mathrm{a}, \mathrm{b}$ shows that they are consistent with each other along the four boundaries. Other variables and the initial conditions have also been checked and consistent patterns were found (not shown here).

\subsection{Emission inventory and emission projections}

Figure 3 shows the distributions of emission differences by the end of the 2050s compared to the present condition. In both the RCP 4.5 and RCP 8.5 scenarios, the mean emissions globally were projected to decrease (Meinshausen et al., 2011), and the US is the region with a large decrease in both NMVOC and $\mathrm{NO}_{\mathrm{x}}$ emissions. In the US, the decrease of emissions is concentrated in the Eastern US, where most of the population and industry are located. In the Western US, the major cities are the main areas of emission reductions. Canada and Mexico show a decrease of $\mathrm{NO}_{\mathrm{x}}$ emissions in both scenarios, while in Mexico, NMVOC increases under RCP 8.5 and in Canada, NMVOC increases under RCP 4.5.

As 2005 represents the start year of RCP scenarios in the US, the 2005 US EPA's National Emission Inventory ${ }^{3}$ was processed by Sparse Matrix Operator Kernel Emissions

\footnotetext{
${ }^{3} \mathrm{http}: / / \mathrm{www} . e p a . g o v / \mathrm{ttn} / \mathrm{chief} /$ net/2005inventory.html\# inventorydata
}

(SMOKE) 2.7 and daily and hourly variations were included during the emission process. The 2005 emissions were used to scale back the emissions from 2001-2004. The scaling ratios for the US anthropogenic emission from 2001 to 2004 are listed in Table 2, according to US EPA emissions trend data $^{4}$. In Table 2, emissions in 2005 are listed with the unit of Tg (Teragram), the emissions of the other years are listed as a ratio of the respective 2005 value. The projections of future emissions in RCP 4.5 and RCP 8.5 are based on the RCP database ${ }^{5}$. Biogenic Emissions Inventory System (BEIS) Modeling 3.14 was used to generate hourly biogenic emissions for each year at present (2001-2004) and future (2057-2059) climate. The calculation of biogenic emissions used empirical methods based on temperature at $2 \mathrm{~m}$ and solar radiation (Guenther et al., 1993; Schwede et al., 2005). The biogenic emissions for the year of 2005 were obtained from the US EPA ${ }^{6}$ and the ratios of present and future biogenic emissions to the year of 2005 , as well as the total NMVOC combining anthropogenic and biogenic emissions, were shown in Table 2.

As depicted in Table 2, most anthropogenic emissions in the US will decrease under both RCP 4.5 and RCP 8.5 scenarios. By the end of the 2050s, CO decreases by more than $70 \%$; non-methane volatile organic compounds (NMVOC) and nitrogen oxides $\left(\mathrm{NO}_{\mathrm{x}}\right)$ decrease by almost $70 \%$ and $50 \%$ in RCP 8.5 , and $40 \%$ and $60 \%$ in RCP 4.5. In contrast, ammonia $\left(\mathrm{NH}_{3}\right)$ emissions increase in both scenarios, and methane (CH4) emissions increase by $60 \%$ in RCP 8.5. The biogenic NMVOC in the US is $31.739 \mathrm{Tg}$ in 2005 , which is $72 \%$ higher than anthropogenic NMVOC $(18.421 \mathrm{Tg})$. Under RCP scenarios, anthropogenic emissions are projected to decrease, while biogenic emissions are projected to increase due to increased temperature. The combined effect leads to about only $10 \%$ reduction of total NMVOC by the end of the 2050s. The biogenic NO emissions (not shown here) are relatively small, accounting for $6 \%$ compared to that from anthropogenic emission in the year of 2005. The future change of biogenic NO emissions are small as well due to less sensitivity to temperature compared to VOC. Please note as the global chemistry CAM-Chem runs held the biogenic emissions constant between 2000 and the 2050s, the large effect of biogenic NMVOC emissions could cause an ozone difference between CAM-Chem and CMAQ.

\section{Evaluation of regional model outputs}

Statistical evaluation by matching observations and model outputs temporally and spatially is commonly used in the studies driven by reanalysis meteorology, and benchmarks have been established for evaluation criteria (USEPA, 2007).

\footnotetext{
${ }^{4}$ http://www.epa.gov/ttn/chief/trends/index.html\#tables

${ }^{5} \mathrm{http}: / /$ www.iiasa.ac.at/web-apps/tnt/RcpDb/dsd?Action= htmlpagel\&page=welcome

${ }^{6}$ http://www.epa.gov/ttnchie1/emch/
} 


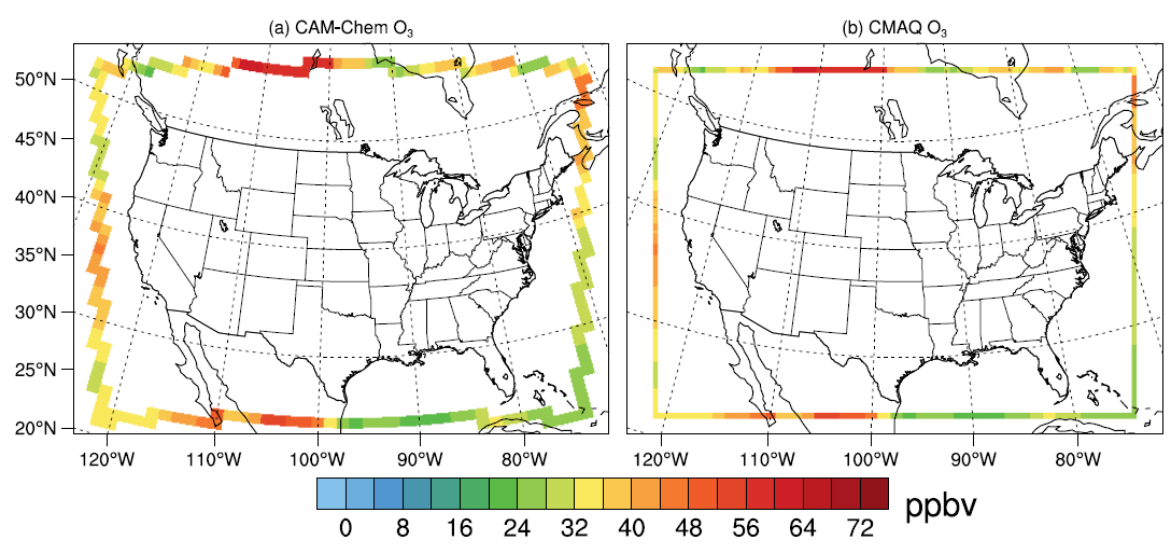

Fig. 2. Boundary comparisons between CAM-Chem and CMAQ for $\mathrm{O}_{3}$ concentrations on 1 July 2001, as an example.

Table 2. Anthropogenic and biogenic emissions compared to base year (2005) emissions in the US.

\begin{tabular}{|c|c|c|c|c|c|c|c|c|c|c|c|}
\hline & \multicolumn{4}{|c|}{ Present climate } & \multirow[t]{2}{*}{$2005(\mathrm{Tg})$} & \multicolumn{3}{|c|}{$\mathrm{RCP} 4.5$} & \multicolumn{3}{|c|}{ RCP 8.5} \\
\hline & 2001 & 2002 & 2003 & 2004 & & 2057 & 2058 & 2059 & 2057 & 2058 & 2059 \\
\hline $\mathrm{CO}$ & 1.142 & 1.194 & 1.129 & 1.065 & 93.030 & 0.272 & 0.268 & 0.264 & 0.246 & 0.243 & 0.240 \\
\hline $\mathrm{NO}_{\mathrm{x}}$ & 1.139 & 1.117 & 1.078 & 1.039 & 18.914 & 0.342 & 0.338 & 0.334 & 0.493 & 0.487 & 0.482 \\
\hline $\mathrm{PM}_{10}$ & 1.121 & 1.008 & 1.006 & 1.003 & 21.149 & 0.552 & 0.552 & 0.551 & 0.542 & 0.540 & 0.538 \\
\hline $\mathrm{PM}_{2.5}$ & 1.282 & 1.022 & 1.015 & 1.007 & 5.456 & 0.761 & 0.754 & 0.747 & 0.422 & 0.417 & 0.413 \\
\hline $\mathrm{SO}_{2}$ & 1.092 & 1.012 & 1.008 & 1.004 & 14.594 & 0.169 & 0.166 & 0.163 & 0.148 & 0.137 & 0.126 \\
\hline NMVOC & 0.929 & 1.149 & 1.112 & 1.074 & 18.421 & 0.632 & 0.630 & 0.628 & 0.314 & 0.310 & 0.306 \\
\hline BG-VOC $^{1}$ & 0.913 & 0.971 & 1.008 & 0.993 & 31.739 & 1.111 & 1.098 & 1.173 & 1.266 & 1.212 & 1.275 \\
\hline $\mathrm{T}-\mathrm{VOC}^{2}$ & 0.919 & 1.036 & 1.046 & 1.023 & 50.160 & 0.935 & 0.926 & 0.973 & 0.916 & 0.881 & 0.919 \\
\hline $\mathrm{NH}_{3}$ & 0.904 & 1.012 & 1.008 & 1.004 & 4.085 & 1.254 & 1.253 & 1.252 & 1.536 & 1.544 & 1.551 \\
\hline $\mathrm{CH}_{4}{ }^{3}$ & 1.202 & 1.187 & 1.172 & 1.156 & 32.180 & 0.893 & 0.888 & 0.883 & 1.612 & 1.626 & 1.640 \\
\hline $\mathrm{BC}$ & 1.007 & 1.005 & 1.004 & 1.002 & 0.394 & 0.723 & 0.716 & 0.709 & 0.264 & 0.262 & 0.260 \\
\hline $\mathrm{OC}$ & 1.145 & 1.109 & 1.073 & 1.036 & 1.141 & 1.060 & 1.051 & 1.042 & 0.609 & 0.606 & 0.604 \\
\hline
\end{tabular}

${ }^{1}$ BG-VOC indicates biogenic VOC emissions.

${ }^{2} \mathrm{~T}-\mathrm{VOC}$ indicates the summation of anthropogenic NMVOC and biogenic VOC

${ }^{3} \mathrm{CH}_{4}$ indicates methane emissions.

Regional climate modeling is able to improve the representation of climate by incorporating the high-resolution topography and land use information (Gao et al., 2012). Although the boundary impact from the global climate models exists, the improved climate in regional modeling favors the paired time and space evaluation. Another important factor to consider is the emission inventory. Previous studies typically used a single year's emission inventory to represent 3 to $4 \mathrm{yr}$ present conditions. For instance, Nolte at al. (2008) used the year 1999 to represent 1999-2003, and Lam et al. (2011) used the year 2000 to represent 1999-2001. The emissions themselves contain large biases without accounting for the interannual variations. We therefore take further steps to consider the emission inter-annual variations. Also, for the year 2005, we use SMOKE to process emission inventory using NEI emission inventory, considering diurnal variations. Thus, we compare hourly observations with model outputs.
All the observations from the US EPA Air Quality System $\left(\mathrm{AQS}^{7}\right)$ are used to evaluate the present climate period from 2001-2004. A statistical evaluation of the pairing of the gas species outputs $\left(\mathrm{CO}, \mathrm{NO}_{2}\right.$ and $\left.\mathrm{O}_{3}\right)$ in time (hourly) and space (observational sites the corresponding model grids) between CMAQ outputs and AQS datasets is shown in Table 3. The benchmarks in the retrospective study (US EPA, 2007) are also listed in the Table 3. The comparison between the climate statistical metrics and the retrospective benchmarks could provide important references for future climate studies.

There are three groups of metrics: Mean Fractional Bias/Mean Fractional Error (MFB/MFE, \%); Normalized Mean Bias/Normalized Mean Error (NMB/NME); and Mean Normalized Bias (MNB) and Mean Normalized Error (MNE). The equations for these six metrics are listed in the

\footnotetext{
${ }^{7} \mathrm{http}: / / w w w . e p a . g o v / \mathrm{ttn} /$ airs/airsaqs/detaildata/ downloadaqsdata.htm
} 


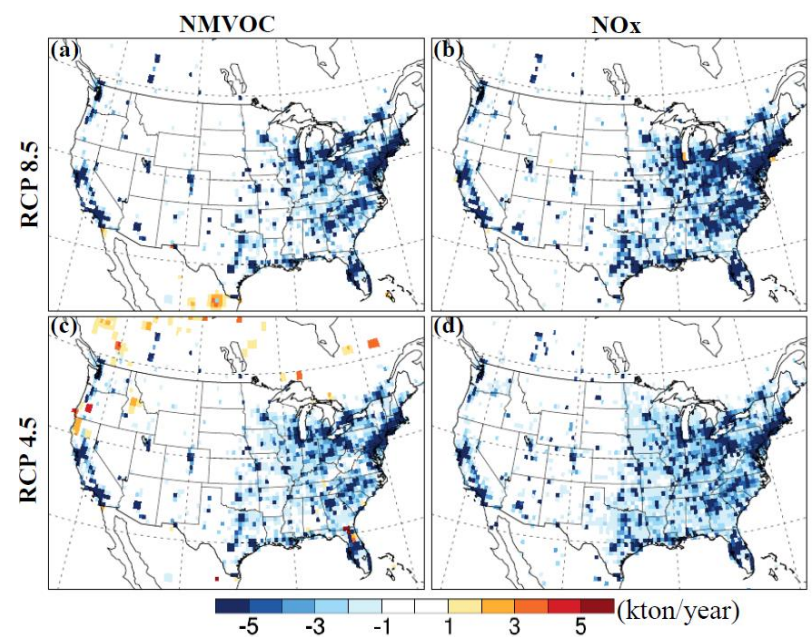

Fig. 3. Differences of NMVOCs and $\mathrm{NO}_{\mathrm{x}}$ between 2005 and 2060 (2060-2005) under RCP 4.5 and RCP 8.5.

supplement. According to the US EPA (2007), the benchmarks of MFB/MFE are $\pm 15 / 35$ for ozone. Among all these metrics, the MFB and MFE are the least biased, and the MNB and MNE are the most biased and, thus, the least useful metrics, particularly when observation values are small. Thus, MNB and MNE are only calculated for $\mathrm{O}_{3}$ with 40 and $60 \mathrm{ppb}$ cutoff values, according to US EPA guidelines (2007). The implementation of cutoff values indicates that sites with ozone concentrations smaller than the cutoff values were discarded in the evaluation. Considering all the AQS sites from 2001-2004, all statistical metrics for $\mathrm{O}_{3}$ with 40 ppbv cutoff meet the benchmark from the US EPA (2007). For $\mathrm{O}_{3}$ with the $60 \mathrm{ppbv}$ cutoff, the absolute errors are less than $30 \%$, while biases for all three metrics (MFB/NMB/MNB) are slightly lower than $-15 \%$. No benchmarks are available for $\mathrm{CO}$ and $\mathrm{NO}_{2}$, and the biases are all less than $50 \%$, with most of the mean errors less than $85 \%$.

The statistical evaluation shows strong evidence that highresolution regional downscaling could achieve reasonably good performance, particularly for MFB/MFE, with the results being comparable to the benchmarks used in the retrospective study.

\section{Ozone concentration changes under future emission and climate conditions}

\subsection{Zonal mean vertical ozone changes in Northern Hemisphere from CAM-Chem}

Before looking at regional air quality using CMAQ outputs, patterns of ozone change in the Northern Hemisphere $(\mathrm{NH})$ from CAM-Chem were evaluated. Zonal mean vertical ozone changes under future climate (2057-2059) for RCP 4.5 (top panel) and RCP 8.5 (bottom panel), compared
Table 3. Statistical evaluations of CMAQ outputs in comparison to AQS.

\begin{tabular}{lrrrr}
\hline & $\mathrm{CO}$ & $\mathrm{NO}_{2}$ & $\mathrm{O}_{3-40}$ & \multicolumn{1}{c}{$\mathrm{O}_{3-60^{2}}$} \\
\hline MFB & $-29 \pm 2$ & $-9 \pm 3$ & $-5 \pm 1$ & $-21 \pm 1$ \\
MFE & $83 \pm 3$ & $80 \pm 1$ & $27 \pm 1$ & $28 \pm 1$ \\
NMB & $-41 \pm 2$ & $-4 \pm 3$ & $-1 \pm 1$ & $-17 \pm 1$ \\
NME & $63 \pm 1$ & $71 \pm 2$ & $25 \pm 1$ & $24 \pm 1$ \\
MNB & - & - & $1 \pm 1$ & $-16 \pm 1$ \\
MNE & - & - & $26 \pm 1$ & $23 \pm 1$ \\
Benchmark $^{3}$ & & & $15 / 35$ & $15 / 35$ \\
\hline
\end{tabular}

${ }^{1}$ A cutoff value of $40 \mathrm{ppbv}$ is set. The cutoff value of $40 \mathrm{ppbv}$ means the observational sites with hourly ozone concentrations less than $40 \mathrm{ppbv}$ were discarded in the evaluation.

${ }^{2}$ A cutoff value of $60 \mathrm{ppbv}$ is set.

3 The benchmark only applies to MFB/MFE.

with present climate (2001-2004) were shown in Fig. 4. In both scenarios, dramatic ozone increase occurs in the highlatitude areas from the upper troposphere $(\sim 300-200 \mathrm{hPa})$ to the tropopause and lower stratosphere, particularly in spring and winter, resulting from the increased stratospheretroposphere exchange (STE). A previous study indicates the STE could reach close to (in RCP 4.5) or more (in RCP 8.5) than twice as large as the present level by the end of $21 \mathrm{st}$ century (Kawase et al., 2011). The increased ozone concentrations in the high-latitude stratosphere reflects the ozone recovery resulting from the reduction in halogens concentrations (Eyring et al., 2010), while the decreased ozone in the tropical stratosphere is caused by the stronger BrewerDobson circulation (BDC) (Kawase et al., 2011; Young et al., 2013).

For the lower troposphere, both scenarios show strong seasonal variations. In RCP 4.5 (Fig. 4, top panel), the largest ozone decrease (4 to $10 \mathrm{ppbv}$ ) occurs in summer and fall from mid- to high latitudes across the lower to mid-troposphere (surface to $\sim 200 \mathrm{hPa}$ ). This is mainly driven by the large reductions of anthropogenic emissions in these areas and strong photochemical reactions in these two seasons. Although the same amount of emissions has been reduced, the ozone decrease in spring was not necessarily significant due to the low photochemical activity. In winter, however, a slight increase ( $0-2 \mathrm{ppbv})$ was projected in the mid- to high latitudes, resulting from the combined effects of low photochemical reaction rates and enhanced STE. The RCP 8.5 scenario (Fig. 4, bottom panel) shows widespread increase in ozone levels as a result of the dramatic increase of methane emissions. The ozone concentrations undergo a larger increase in winter and spring (2-6 ppbv) than summer and fall $(0-4 \mathrm{ppbv})$ in the lower troposphere (surface to $\sim 800 \mathrm{hPa}$ ). This is the result of a higher reduced ozone production rate, resulting from large reduction in anthropogenic emission in summer and fall than the other two seasons. The ozone increase in the mid-troposphere ( $800 \mathrm{hPa}$ to $300 \mathrm{hPa}$ ) tends to show less seasonal variation, with an increase of 4-10 ppbv. 

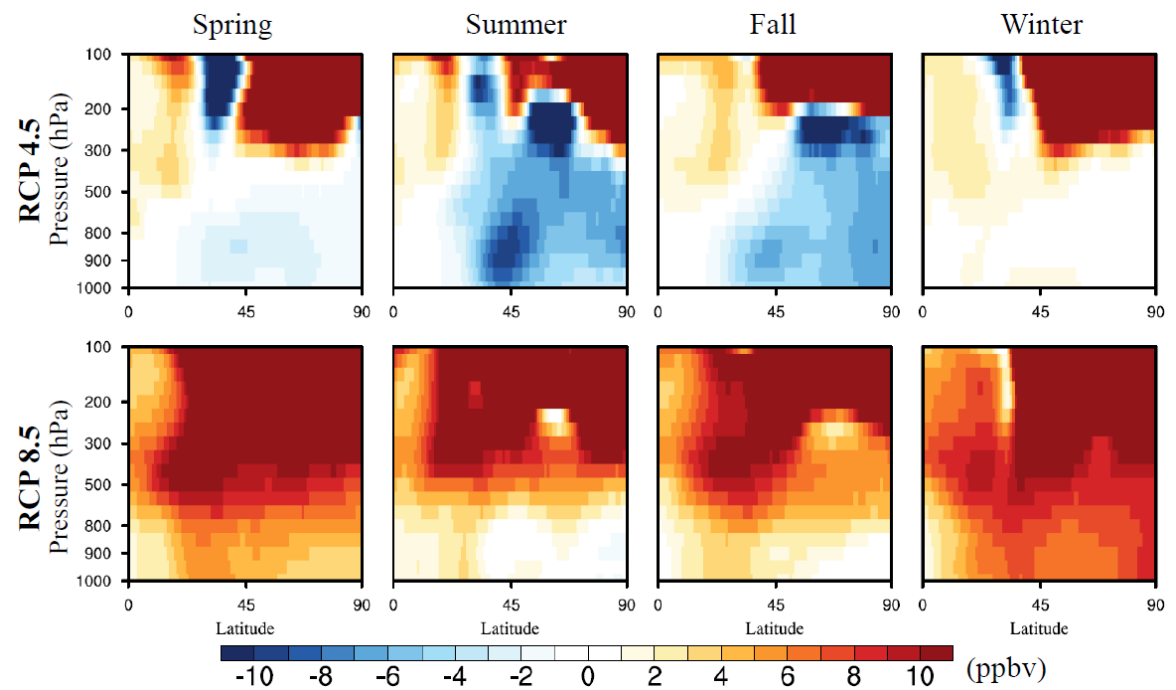

Fig. 4. Zonal mean vertical ozone changes from CAM-Chem under future climate (2057-2059 minus 2001-2004) for RCP 4.5 (top panel) and RCP 8.5 (bottom panel).

\subsection{Seasonal variations of surface ozone concentrations by the end of the 2050s}

After evaluating the global zonal mean ozone changes, we focus on the surface ozone changes in the continental US from regional downscaling simulations. Figure 5 shows seasonal mean surface ozone differences by the end of the 2050s (2057-2059) compared with the present (2001-2004). Under RCP 4.5 scenario, by the end of the $2050 \mathrm{~s}$, in spring, summer, and fall (Fig. 5a-c), significant decreases in ozone concentrations occur across most of the US, resulting from ozone emission precursor reductions (Table 2). In summer, when photochemical reactions are the most active, the large ozone precursor emissions reduction leads to the largest decrease of ozone concentrations, ranging from 6 to $10 \mathrm{ppbv}$. However, a few exceptions occur near major cities, including Seattle (WA), San Francisco (CA), Los Angeles (CA), Phoenix (AZ), Denver (CO), Chicago (IL), New York City (NY) and Atlanta (GA), etc., with ozone increases of 3 to 7 ppbv. The ozone increases, particularly in spring (Fig. 5a), fall (Fig. 5c) and winter (Fig. 5d), in the major cities are mainly due to NO titration by reducing a large percentage of $\mathrm{NO}_{\mathrm{x}}$ emissions ( $\sim 65 \%$ from Table 2$)$. In summer (Fig. $5 \mathrm{~b}$ ), these cities do not show as large an increase as other seasons, largely due to the compensation between less NO titration and reduced photochemical reaction rates resulting from emission reductions. As a result of low chemical reactivity, titration plays a major role in ozone loss in winter; thus, reducing $\mathrm{NO}_{\mathrm{x}}$ leads to large areas of ozone increase (Fig. $5 \mathrm{~d}$ ).

In the RCP 8.5 scenario (Fig. 5e-h), the ozone increase by 3 to $7 \mathrm{ppbv}$ in major cities is similarly driven by weakened NO titration as RCP 4.5. However, compared with RCP 4.5, RCP 8.5 results show some obvious differences. In spring and fall (Fig. 5e, g), there are 3-6 ppbv increases in the Western, Midwestern and part of Northeastern US as well as large areas of Canada. In summer, the majority of US areas show ozone decrease. In winter (Fig. 5h), ozone concentrations increase across nearly the entire domain, ranging from 3 to 10 ppbv.

The spatial distributions of surface ozone changes under both RCP scenarios from CAM-Chem were also evaluated (Fig. S1 in the Supplement). Consistent patterns were found between CAM-Chem and CMAQ though differences exist in the magnitude, partly resulting from the emission differences, in particular the biogenic emission differences explained in Sect. 3.3. Titration effect was also found from CAM-Chem outputs, and a similar phenomenon was reported by Collette et al. (2012) over Europe by using 6 chemistry transport models.

Considering the larger ozone increases in spring and winter in RCP 8.5 compared to RCP 4.5 , and the large increase in methane concentrations in RCP 8.5 , a sensitivity study was conducted to explore the impact of methane on ozone concentrations. Under RCP 8.5, the methane level in 2050 is $2740 \mathrm{ppbv}$, which is $56 \%$ higher than the level in 2000 (1751 ppbv). The simulations were conducted using CAMChem for the period of the 2050s by maintaining the methane concentrations at the 2000 level. Figure 5i-1 shows ozone changes in the 2050s compared to present climate under RCP 8.5 without methane increase. Compared to Fig. $5 \mathrm{e}-\mathrm{h}$, in spring and winter, the ozone increase areas and magnitudes were dramatically reduced, leaving small areas of ozone increase resulting from titration effect. In summer and fall, a much larger decrease (comparing Fig. 5i, k and f, g) occurs when methane concentrations maintain at 2000 level. The sensitivity study clearly addressed the significant role of 


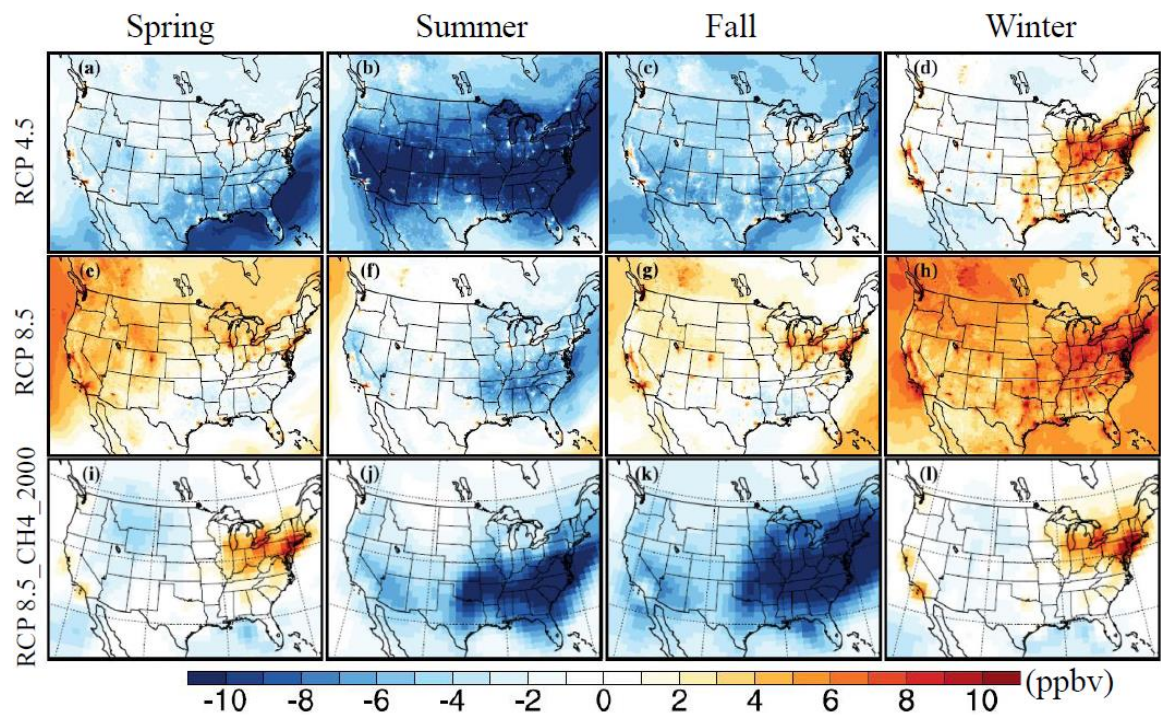

Fig. 5. Seasonal mean surface ozone changes from CMAQ outputs under future climate (2057-2059 minus 2001-2004) for RCP 4.5 (a-d) and RCP $8.5(\mathbf{e}-\mathbf{h})$; the bottom panel (i-l) shows ozone changes from CAM-Chem by the end of the 2050s without methane increases in RCP 8.5 (ozone in the 2050s with 2000s methane concentrations - ozone in 2000s).

methane concentrations play on ozone concentrations, and the impact could be as large as $4-8$ ppbv.

\section{Maximum daily $8 \mathrm{~h}$ ozone changes in nine climate regions in the US}

\section{Maximum daily $8 \mathrm{~h}$ ozone under future climate}

In addition to the seasonal average ozone changes across the entire continental domain, we focus more on air quality in the nine climate regions in the US from the downscaling results. Cumulative distributions of Maximum daily $8 \mathrm{~h}$ ozone (MDA8) for present climate (2001-2004) and future climate (RCP 4.5 and RCP 8.5, 2057-2059) was shown in Fig. 6. All model grids are used for each region in the analysis. Overall, compared with present climate, the cumulative distribution of RCP 4.5 shifts to the lower values, indicating reduced ozone concentrations under the emission reduction scenario RCP 4.5. Comparing RCP 4.5 with RCP 8.5, the right shift of distribution for RCP 8.5 indicates higher ozone concentrations under this scenario. In RCP 8.5, the Northeast, Southeast, Central and South show decreasing patterns in the high ozone concentration levels, (i.e., higher than 50-60 ppbv), yet increasing patterns in the low ozone concentration levels, (i.e., from $20 \mathrm{ppbv}$ to $50 \mathrm{ppbv}$ ). However, the Northwest, West and West North Central show increasing patterns in the ozone level from $30 \mathrm{ppbv}$ to $60 \mathrm{ppbv}$ and little change in the level higher than $60 \mathrm{ppbv}$ to $70 \mathrm{ppbv}$. The difference in ozone change patterns between Eastern and Western US could be attributed to different ozone precursor emission distributions (Fig. 3a, b). Figure 3a, b showed more dense emission dis- tributions in the Eastern US than the Western US. Note there were $10 \mathrm{ppbv}$ or larger differences as described earlier (the Eastern US shows increasing patterns in the ozone level from 20-50 ppbv, while the Western US shows 30-60 ppbv). As is explained in Fig. 5e-h, the ozone increase in RCP 8.5 mainly occurs in spring and winter when the ozone photochemical reactions are not the major driver; the higher background ozone (10-15 ppbv higher in the Western than the Eastern US, Zhang et al., 2011) play the key role in driving the differences.

In addition to the cumulative distributions, the percentage of MDA8 exceeding 60 and 75 ppbv is also listed in Fig. 6. The National Ambient Air Quality Standards (NAAQS) for MDA8 has been 75 ppbv since 2008. As the NAAQS might become more stringent in the future, the $60 \mathrm{ppbv}$ was listed to provide potentially useful information in the years to come. The negative numbers in Fig. 6 indicate ozone exceedance decreases in the future compared with present climate. From Fig. 6, we find that all blue numbers (second row) are negative, indicating ozone concentration decreases in RCP 4.5. However, in RCP 8.5, the exceedance of $60 \mathrm{ppbv}$ increases by $3 \%$ to $10 \%$ in the Western US due to increased methane emissions; the exceedances in the Eastern US decrease by $2 \%$ to $14 \%$, resulting from large anthropogenic emission reductions in the emission dense area. 


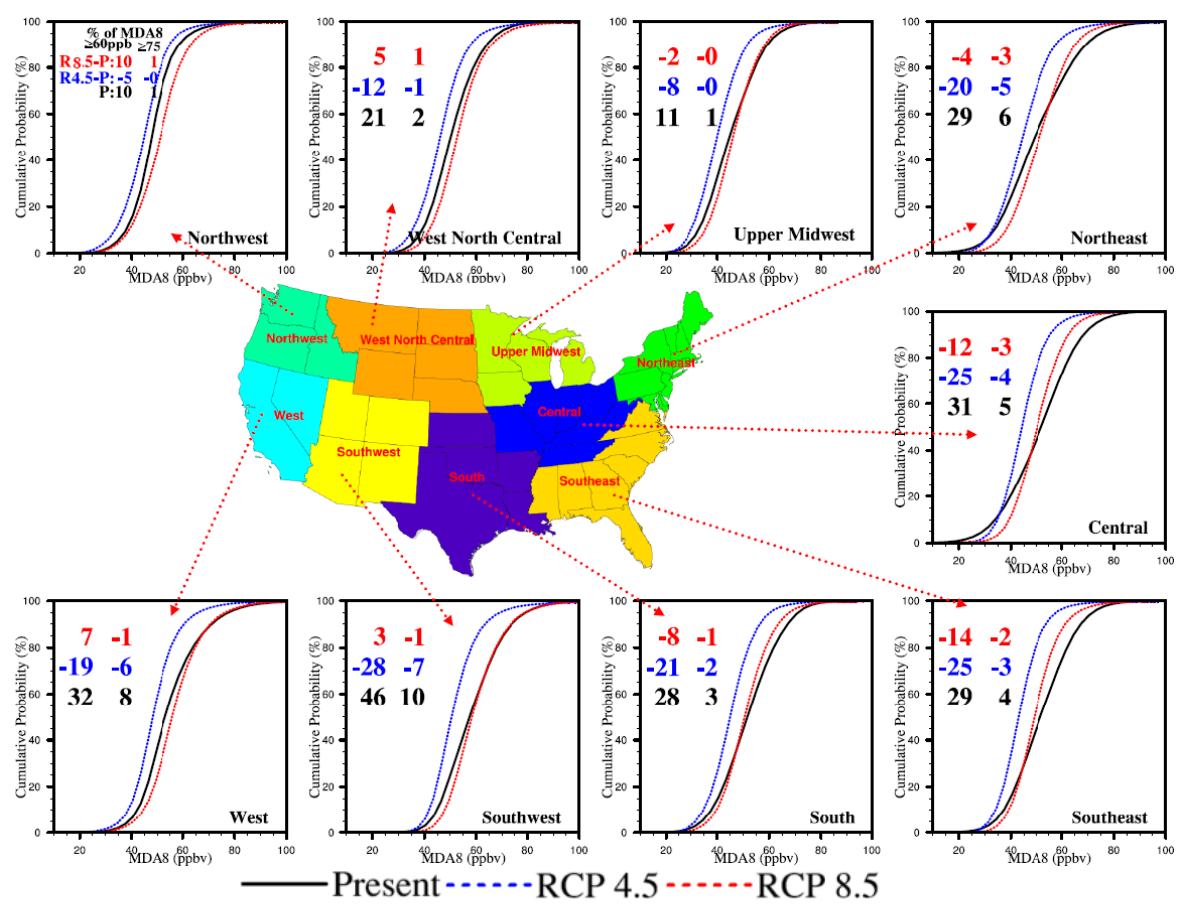

Fig. 6. Cumulative distributions of MDA8 ozone from CMAQ. The black, blue and red colors represent the distributions of MDA 8 at present climate (2001-2004), RCP 4.5 (2057-2059) and RCP 8.5 (2057-2059), respectively. There are two columns of numbers: the numbers on the left show the percentage of MDA8 ozone exceeding $60 \mathrm{ppbv}$ at present, the percentage change in RCP 4.5 (blue) and RCP 8.5 (red) compared with present; the numbers on the right are similar as left but for MDA 8 ozone exceeding 75 ppbv.

\section{More intense heat waves and its impact on air quality}

\subsection{Heat wave duration and frequency}

Until now, studies of climate impact on air quality have focused on the comparison between different climate scenarios or different emissions scenarios (Kawase et al., 2011; Lam et al., 2011; Nolte et al., 2008). However, under the same scenario, different meteorological conditions, in particular a heat wave period, could potentially increase ozone levels (Stedman, 2004). This is a very important concern, particularly for control strategies and policies. Thus, we investigate heat waves under future climate and further evaluate the impact of heat waves on ozone.

Two metrics of heat waves were used in this study: duration (number of days for each heat wave) and frequency (number of heat waves). Daily maximum temperature was used to define a heat wave. It is defined as the longest period that meets the following two criteria: (1) the maximum daily temperature has to reach the 97.5 th percentile of the entire period (2001-2004 in this case) for three or more consecutive days; and (2) during this period, the mean daily maximum temperature is no lower than the 97.5th percentile, and for each day, the daily maximum temperature has to be equal to or higher than the 81st percentile (Huth et al., 2000; Meehl and Tebaldi, 2004; Gao et al., 2012). Definitions of future heat waves use the same thresholds in order to compare the changes between present and future climate.

Figure 7 shows the heat wave duration and frequency at present and future climate. At present (Fig. 7a, b), the heat wave duration ranges from 3.7 to 4.4 days per event, and the number of annual heat wave events are 1 to 1.5 . In RCP 4.5 (Fig. 7c, d), by the end of the 2050s, most of the regions show an increase in heat wave duration, except Central and upper Midwest, which show slight decreases. The mean increase of duration across the entire US is $23 \%$, while the largest increase of $68 \%$ occurs in the Southwest. For the annual number of events, all regions show increasing patterns, with a mean increase in the US of $131 \%$. The frequency in the Northeast and Northwest is more than triple compared with present climate. Far more intense heat waves are projected to occur in RCP 8.5 (Fig. 7e, f), with a mean increase of $54 \%$ and $313 \%$ for duration and frequency, more than twice as high as the increase in RCP 4.5 (23\% and $131 \%)$. The duration increase ranges from $29 \%$ to $90 \%$ among the 9 regions. The increase of events is more significant, with a minimum increase of $173 \%$ in the West and a maximum increase of $564 \%$ in the Northeast. 

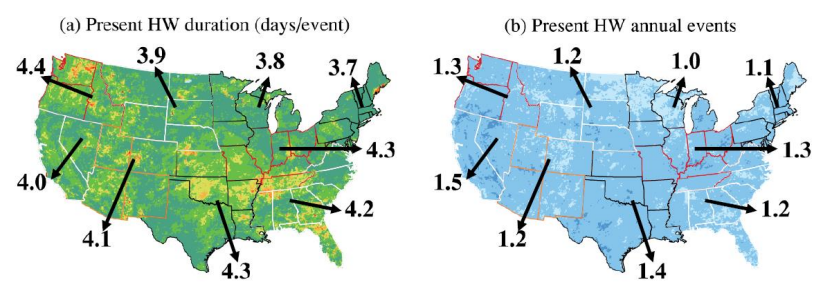

(c) RCP $4.5 \mathrm{HW}$ duration

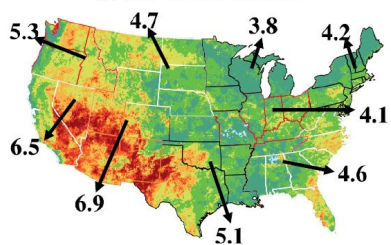

(e) RCP 8.5 HW duration

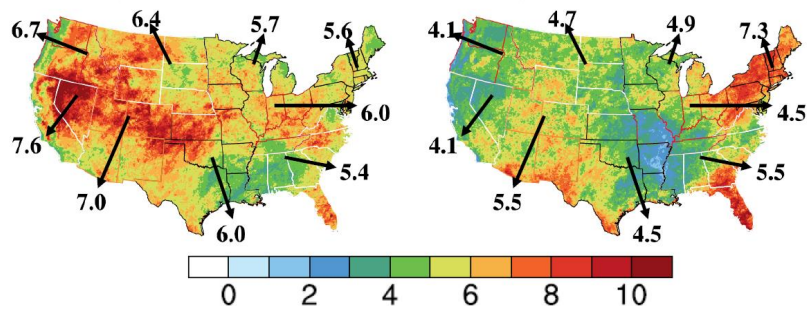

Fig. 7. The heat wave duration and frequency derived from the daily maximum temperature simulated by WRF 3.2.1. The state boundary was labeled with different colors to distinguish different regions as shown in Fig. 1. The numbers next to the arrows represent the regional mean heat wave duration or frequency.

\subsection{Impact of heat waves on MDA8 ozone concentrations}

The heat waves discussed above mostly occur from June to October; we therefore investigated the impact of heat waves during these five months. The sample size of heat wave days is mostly much smaller than non-heat wave days, and the percentage of heat wave days to non-heat wave days ranges from $5 \%$ to $17 \%$ under RCP 4.5 , and $21 \%$ to $35 \%$. The sample size between the entire period (including heat wave and non-heat wave period) and non-heat wave period is similar, thus the MDA8 distributions during entire period and nonheat wave period were shown in Fig. 8. All model grids are used for each climate region in the analysis.

Under RCP 8.5, the mean MDA8 shows increases across the US except in the Southeast, during the entire period compared with non-heat wave period, and the increases are all statistically significant, ranging from $0.3 \mathrm{ppbv}$ to $2.0 \mathrm{ppbv}$. The ozone exceedance of $60 \mathrm{ppbv}$ and $75 \mathrm{ppbv}$ during the non-heat wave period is on average $1-8 \%$ and $0-4 \%$ lower than the entire period respectively. The daily maximum temperature (TMX) under this scenario is statistically higher during the entire period than non-heat wave period, ranging from 0.8 to $2.0^{\circ} \mathrm{C}$. One of the major reasons the Southeast does not show a statistically significant increase in MDA8 is its position adjacent to the ocean and its small diurnal temperature variations (Fig. S2 in the Supplement). Under RCP 4.5, statistically significant MDA8 increase occurs in five regions, however, the increase magnitudes (maximum of $0.7 \mathrm{ppbv}$ ) are much smaller than RCP 8.5. The $95 \%$ confidence interval of the MDA8 differences between entire period and nonheat wave period was also shown in Fig. 8. The upper $95 \%$ limit indicates $0.4 \mathrm{ppbv}$ to $1.5 \mathrm{ppbv}$ increase under RCP 4.5 and $1.2 \mathrm{ppbv}$ to $3.2 \mathrm{ppbv}$ increase under RCP 8.5 resulting from heat waves without including the Southeast (increase of $0.6 \mathrm{ppbv}$ ). Even though the temperature increase in RCP 4.5 due to heat waves is statistically significant, the ozone precursors, including $\mathrm{NMVOC}$ and $\mathrm{NO}_{\mathrm{x}}$, decreased dramatically and the methane emissions decrease by $\sim 10 \%$ (Table 2) as well. As is explained in Sect. 5.2, methane is the major contributor to the ozone increase in RCP 8.5, and without enough ozone precursor emissions in RCP 4.5, the heat waves may not play as significant a role as it does in RCP 8.5.

\section{Conclusions}

In future climate conditions, including both RCP 4.5 and RCP 8.5, the ozone recovery in the stratosphere and increased stratosphere-troposphere exchange (STE) leads to a dramatic ozone increase from the upper troposphere $(\sim 300 \mathrm{hPa})$ to lower stratosphere. In the lower troposphere, ozone change patterns show seasonal variations. In RCP 4.5, the largest decrease occurs in summer and fall, while small changes occur in spring and winter, and are mainly driven by the photochemical reactivity seasonal differences. The RCP 8.5 scenario shows consistent seasonal variations. However, with the large increase of methane emissions, it shows increase of ozone concentrations. The lowest increase occurs in summer and the largest increase occurs in winter.

The dynamical downscaling results are used to explore more details of ozone change in the continental US. By the end of the 2050s, RCP 4.5 scenario shows significant decreases in ozone concentrations across most of the US. However, a few major cities show dramatic ozone increases due to NO titration. In particular, in winter with low chemical reactivity, titration plays a major role in ozone loss. Therefore, reducing $\mathrm{NO}_{\mathrm{x}}$ could lead to large areas of ozone increase. Compared with RCP 4.5, RCP 8.5 shows consistent NO titration effect; but when combined with increased methane emissions, leads to a much less dramatic reduction or even increase (as large as 3-10 ppbv) in ozone. These two scenarios confirm that the reduction of methane emissions will undoubtedly benefit future ozone control. However, the titration effect in major cities with dense population cannot be ignored and reasonable control of $\mathrm{NO}_{\mathrm{x}}$ should be implemented.

Another important issue discussed in this study was the heat wave effect and its impact on ozone concentrations. Our results show significant impact of heat waves on MDA8 ozone. Much more intense heat waves, including both in 


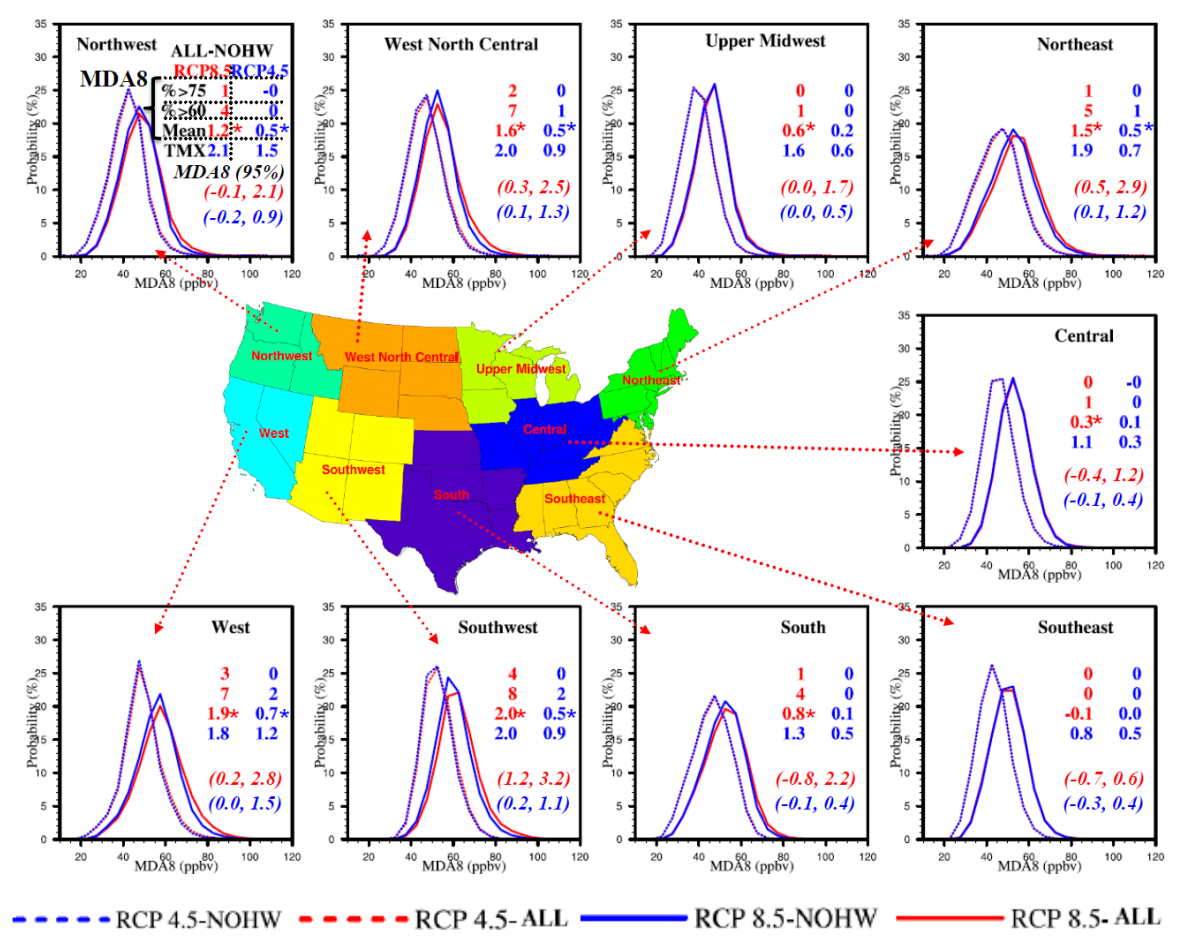

Fig. 8. Distributions of MDA8 during the entire period (referred to as ALL) and non-heat wave period (referred to as NOHW) for RCP 4.5 and RCP 8.5 from June to October. There are two columns of numbers (top four rows), and they represent the percentage of MDA8 ozone exceeding $70 \mathrm{ppbv}$ (top row) and $60 \mathrm{ppbv}$ (second row), mean MDA8 ozone (third row, with unit of ppbv) and mean daily maximum temperature (TMX, fourth row, with unit of ${ }^{\circ} \mathrm{C}$ ) for both scenarios. The bottom two row numbers in italics in parentheses represent the $95 \%$ confidence interval of MDA8 differences (ppbv) between the entire period and non-heat wave period under RCP 8.5 (red numbers) and RCP 4.5 (blue numbers). Statistical significance was tested and marked with a star to indicate statistical significant at the level of 0.05 . All TMX mean differences are statistically significant.

duration and frequency, were projected to occur in RCP 8.5. There is a statistical significant increase (1.2 ppbv to $3.2 \mathrm{ppbv}$ in terms of the upper $95 \%$ confidence limit) of MDA8 ozone across the US, except in the Southeast, during the entire period compared with non-heat wave period. Without methane increases, the impact of heat waves tend to be weaker, as shown in RCP 4.5 (about half of the US regions show statistically significant increases of MDA8). Both scenarios implemented significant decreases of anthropogenic NMVOC and $\mathrm{NO}_{\mathrm{x}}$, if these emissions were not reduced as large as the projected scenarios, the impact of heat waves on ozone formation could be even larger. These findings address important issues regarding future air quality control, indicating that the ozone may be better controlled by reducing both ozone precursor emission and greenhouse gases emission.

\section{Supplementary material related to this article is available online at http://www.atmos-chem-phys.net/13/ 9607/2013/acp-13-9607-2013-supplement.pdf.}

Acknowledgements. Model simulations of this research were partially supported by the National Science Foundation through TeraGrid resources provided by National Institute for Computational Sciences (NICS) (TG-ATM110009 and UT-TENN0006). It also used resources of the Oak Ridge Leadership Computing Facility at the Oak Ridge National Laboratory, which is supported by the Office of Science of the US Department of Energy (Contract No. DE-AC05-00OR22725). Data analysis was sponsored by the Climate and Health program led by George Luber at the Centers for Disease Control and Prevention (CDC) (5 U01 EH000405). Yang Gao was partly supported by the Office of Science of the US Department of Energy as part of the Regional and Global Climate Modeling Program. The Pacific Northwest National Laboratory is operated for DOE by Battelle Memorial Institute under contract DE-AC05-76RL01830. The CESM project is supported by the National Science Foundation and the Office of Science (BER) of the US Department of Energy. The National Center for Atmospheric Research is operated by the University Corporation for Atmospheric Research under sponsorship of the National Science Foundation.

Edited by: A. Dastoor 


\section{References}

Aghedo, A. M., Bowman, K. W., Worden, H. M., Kulawik, S. S., Shindell, D. T., Lamarque, J. F., Faluvegi, G., Parrington, M., Jones, D. B. A., and Rast, S.: The vertical distribution of ozone instantaneous radiative forcing from satellite and chemistry climate models, J. Geophys. Res., 116, D01305, doi:10.1029/2010jd014243, 2011.

Annan, J. D. and Hargreaves, J. C.: Understanding the CMIP3 Multimodel Ensemble, J. Climate, 24, 4529-4538, doi:10.1175/2011jcli3873.1, 2011

Bell, M., Goldberg, R., Hogrefe, C., Kinney, P., Knowlton, K., Lynn, B., Rosenthal, J., Rosenzweig, C., and Patz, J.: Climate change, ambient ozone, and health in 50 US cities, Climatic Change, 82, 61-76, doi:10.1007/s10584-006-9166-7, 2007.

Byun, D. and Schere, K. L.: Review of the governing equations, computational algorithms, and other components of the models3 Community Multiscale Air Quality (CMAQ) modeling system, Appl. Mech. Rev., 59, 51-77, doi:10.1115/1.2128636, 2006.

Caldwell, P., Chin, H.-N. S., Bader, D. C., and Bala, G.: Evaluation of a WRF dynamical downscaling simulation over California, Climatic Change, 95, 499-521, doi:10.1007/s10584-009-95835, 2009.

Carlton, A. G., Bhave, P. V., Napelenok, S. L., Edney, E. O., Sarwar, G., Pinder, R. W., Pouliot, G. A., and Houyoux, M.: Model Representation of Secondary Organic Aerosol in CMAQv4.7, Environ. Sci. Technol., 44, 8553-8560, doi:10.1021/es100636q, 2010.

Chen, F. and Dudhia, J.: Coupling an Advanced Land SurfaceHydrology Model with the Penn State-NCAR MM5 Modeling System. Part I: Model Implementation and Sensitivity, Mon. Weather. Rev., 129, 569-585, doi:10.1175/15200493(2001)129<0569:caalsh>2.0.co;2, 2001.

Colette, A., Granier, C., Hodnebrog, Ø., Jakobs, H., Maurizi, A., Nyiri, A., Rao, S., Amann, M., Bessagnet, B., D'Angiola, A., Gauss, M., Heyes, C., Klimont, Z., Meleux, F., Memmesheimer, M., Mieville, A., Rouill, L., Russo, F., Schucht, S., Simpson, D., Stordal, F., Tampieri, F., and Vrac, M.: Future air quality in Europe: a multi-model assessment of projected exposure to ozone, Atmos. Chem. Phys., 12, 10613-10630, doi:10.5194/acp12-10613-2012, 2012.

Emmons, L. K., Walters, S., Hess, P. G., Lamarque, J.-F., Pfister, G. G., Fillmore, D., Granier, C., Guenther, A., Kinnison, D., Laepple, T., Orlando, J., Tie, X., Tyndall, G., Wiedinmyer, C., Baughcum, S. L., and Kloster, S.: Description and evaluation of the Model for Ozone and Related chemical Tracers, version 4 (MOZART-4), Geosci. Model Dev., 3, 43-67, doi:10.5194/gmd3-43-2010, 2010.

Eyring, V., Cionni, I., Bodeker, G. E., Charlton-Perez, A. J., Kinnison, D. E., Scinocca, J. F., Waugh, D. W., Akiyoshi, H., Bekki, S., Chipperfield, M. P., Dameris, M., Dhomse, S., Frith, S. M., Garny, H., Gettelman, A., Kubin, A., Langematz, U., Mancini, E., Marchand, M., Nakamura, T., Oman, L. D., Pawson, S., Pitari, G., Plummer, D. A., Rozanov, E., Shepherd, T. G., Shibata, K., Tian, W., Braesicke, P., Hardiman, S. C., Lamarque, J. F., Morgenstern, O., Pyle, J. A., Smale, D., and Yamashita, Y.: Multimodel assessment of stratospheric ozone return dates and ozone recovery in CCMVal-2 models, Atmos. Chem. Phys., 10, 94519472, doi:10.5194/acp-10-9451-2010, 2010.
Fiore, A. M., Naik, V., Spracklen, D. V., Steiner, A., Unger, N., Prather, M., Bergmann, D., Cameron-Smith, P. J., Cionni, I., Collins, W. J., Dalsoren, S., Eyring, V., Folberth, G. A., Ginoux, P., Horowitz, L. W., Josse, B., Lamarque, J.-F., MacKenzie, I. A., Nagashima, T., O’Connor, F. M., Righi, M., Rumbold, S. T., Shindell, D. T., Skeie, R. B., Sudo, K., Szopa, S., Takemura, T., and Zeng, G.: Global air quality and climate, Chem. Soc. Rev., 41, 6663-6683, 2012.

Fu, J. S., Dong, X., Gao, Y., Wong, D. C., and Lam, Y. F.: Sensitivity and linearity analysis of ozone in East Asia: The effects of domestic emission and intercontinental transport, J. Air Waste Manag. Assoc., 62, 1102-1114, doi:10.1080/10962247.2012.699014, 2012a.

Fu, J. S., Hsu, N. C., Gao, Y., Huang, K., Li, C., Lin, N.-H., and Tsay, S.-C.: Evaluating the influences of biomass burning during 2006 BASE-ASIA: a regional chemical transport modeling, Atmos. Chem. Phys., 12, 3837-3855, doi:10.5194/acp-12-38372012, 2012b.

Ganguly, A. R., Steinhaeuser, K., Erickson, D. J., Branstetter, M., Parish, E. S., Singh, N., Drake, J. B., and Buja, L.: Higher trends but larger uncertainty and geographic variability in 21 st century temperature and heat waves, P. Natl. Acad. Sci. USA, 106 , 15555-15559, 2009.

Gao, Y., Fu, J. S., Drake, J. B., Liu, Y., and Lamarque, J.-F.: Projected changes of extreme weather events in the Eastern United States based on a high-resolution climate modeling system, Environ. Res. Lett., 7, 044025, doi:10.1088/1748-9326/7/4/044025, 2012.

Guenther, A., Zimmerman, P., Harley, P., Monson, R., and Fall, R.: Isoprene and monoterpene emission rate variability: Model evaluation and sensitivity analysis, J. Geophys. Res., 98, 1260912617, doi:10.1029/93JD00527, 1993.

Hack, J. J., Caron, J. M., Yeager, S. G., Oleson, K. W., Holland, M. M., Truesdale, J. E., and Rasch, P. J.: Simulation of the Global Hydrological Cycle in the CCSM Community Atmosphere Model Version 3 (CAM3): Mean Features, J. Climate, 19, 2199-2221, doi:10.1175/jcli3755.1, 2006.

Holtslag, A. A. M. and Boville, B. A.: Local Versus Nonlocal Boundary-Layer Diffusion in a Global Climate Model, J. Climate, 6, 1825-1842, doi:10.1175/15200442(1993)006<1825:lvnbld>2.0.co;2, 1993.

Hong, S.-Y. and Lim, J.-O.: The WRF Single-Moment 6-Class Microphysics Scheme (WSM6), J. Korean Meteor. Soc., 42, 129 151, 2006.

Huang, H.-C., Lin, J., Tao, Z., Choi, H., Patten, K., Kunkel, K., Xu, M., Zhu, J., Liang, X.-Z., Williams, A., Caughey, M., Wuebbles, D. J., and Wang, J.: Impacts of long-range transport of global pollutants and precursor gases on U.S. air quality under future climatic conditions, J. Geophys. Res., 113, D19307, doi:10.1029/2007jd009469, 2008.

Huang, K., Fu, J. S., Hsu, N. C., Gao, Y., Dong, X., Tsay, S.-C., and Lam, Y. F.: Impact assessment of biomass burning on air quality in Southeast and East Asia during BASE-ASIA, Atmos. Environ., 78, 291-302, doi:10.1016/j.atmosenv.2012.03.048, 2013.

Hunke, E. C. and Lipscomb, W. H.: CICE: the Los Alamos Sea Ice Model, Documentation and Software, Version 4.0, Los Alamos National Laboratory Tech. Rep. LA-CC-06-012., 2008. 
Huth, R., Kysely, J., and Pokorna, L.: GCM simulation of heat waves, dry spells, and their relationships to circulation, Climatic Change, 46, 29-60, 2000.

Iacono, M. J., Delamere, J. S., Mlawer, E. J., Shephard, M. W., Clough, S. A., and Collins, W. D.: Radiative forcing by long-lived greenhouse gases: Calculations with the AER radiative transfer models, J. Geophys. Res., 113, D13103, doi:10.1029/2008jd009944, 2008.

Jacob, D. J. and Winner, D. A.: Effect of climate change on air quality, Atmos. Environ., 43, 51-63, doi:10.1016/j.atmosenv.2008.09.051, 2009.

Janjić, Z. I.: The Step-Mountain Coordinate: Physical Package, Mon. Weather. Rev., 118, 1429-1443, doi:10.1175/15200493(1990)118<1429:tsmcpp>2.0.co;2, 1990.

Kain, J. S.: The Kain-Fritsch Convective Parameterization: An Update, J. Appl. Meteorol., 43, 170-181, doi:10.1175/15200450(2004)043<0170:tkcpau>2.0.co;2, 2004.

Kawase, H., Nagashima, T., Sudo, K., and Nozawa, T.: Future changes in tropospheric ozone under Representative Concentration Pathways (RCPs), Geophys. Res. Lett., 38, L05801, doi:10.1029/2010g1046402, 2011.

Kelly, J., Makar, P. A., and Plummer, D. A.: Projections of mid-century summer air-quality for North America: effects of changes in climate and precursor emissions, Atmos. Chem. Phys., 12, 5367-5390, doi:10.5194/acp-12-5367-2012, 2012.

Knutti, R. and Sedlacek, J.: Robustness and uncertainties in the new CMIP5 climate model projections, Nature Clim. Change, 3, 369373, doi:10.1038/nclimate1716, 2013.

Lam, Y. F. and Fu, J. S.: A novel downscaling technique for the linkage of global and regional air quality modeling, Atmos. Chem. Phys., 9, 9169-9185, doi:10.5194/acp-9-9169-2009, 2009.

Lam, Y. F., Fu, J. S., Wu, S., and Mickley, L. J.: Impacts of future climate change and effects of biogenic emissions on surface ozone and particulate matter concentrations in the United States, Atmos. Chem. Phys., 11, 4789-4806, doi:10.5194/acp-11-47892011, 2011.

Lamarque, J.-F. and Solomon, S.: Impact of Changes in Climate and Halocarbons on Recent Lower Stratosphere Ozone and Temperature Trends, J. Climate, 23, 2599-2611, doi:10.1175/2010jcli3179.1, 2010.

Lamarque, J. F., Kiehl, J. T., Hess, P. G., Collins, W. D., Emmons, L. K., Ginoux, P., Luo, C., and Tie, X. X.: Response of a coupled chemistry-climate model to changes in aerosol emissions: Global impact on the hydrological cycle and the tropospheric burdens of $\mathrm{OH}$, ozone, and $\mathrm{NO}_{\mathrm{x}}$, Geophys. Res. Lett., 32, L16809, doi:10.1029/2005g1023419, 2005.

Lamarque, J.-F., Kyle, G., Meinshausen, M., Riahi, K., Smith, S., van Vuuren, D., Conley, A., and Vitt, F.: Global and regional evolution of short-lived radiatively-active gases and aerosols in the Representative Concentration Pathways, Climatic Change, 109, 191-212, doi:10.1007/s10584-011-0155-0, 2011a.

Lamarque, J.-F., McConnell, J. R., Shindell, D. T., Orlando, J. J., and Tyndall, G. S.: Understanding the drivers for the 20th century change of hydrogen peroxide in Antarctic ice-cores, Geophys. Res. Lett., 38, L04810, doi:10.1029/2010g1045992, 2011 b.

Lamarque, J.-F., Emmons, L. K., Hess, P. G., Kinnison, D. E., Tilmes, S., Vitt, F., Heald, C. L., Holland, E. A., Lauritzen, P. H., Neu, J., Orlando, J. J., Rasch, P. J., and Tyndall, G. K.: CAM-chem: description and evaluation of interactive at- mospheric chemistry in the Community Earth System Model, Geosci. Model Dev., 5, 369-411, doi:10.5194/gmd-5-369-2012, 2012.

Lamarque, J.-F., Shindell, D. T., Josse, B., Young, P. J., Cionni, I., Eyring, V., Bergmann, D., Cameron-Smith, P., Collins, W. J., Doherty, R., Dalsoren, S., Faluvegi, G., Folberth, G., Ghan, S. J., Horowitz, L. W., Lee, Y. H., MacKenzie, I. A., Nagashima, T., Naik, V., Plummer, D., Righi, M., Rumbold, S. T., Schulz, M., Skeie, R. B., Stevenson, D. S., Strode, S., Sudo, K., Szopa, S., Voulgarakis, A., and Zeng, G.: The Atmospheric Chemistry and Climate Model Intercomparison Project (ACCMIP): overview and description of models, simulations and climate diagnostics, Geosci. Model Dev., 6, 179-206, doi:10.5194/gmd-6-179-2013, 2013.

Mass, C. F., Ovens, D., Westrick, K., and Colle, B. A.: Does Increasing Horizontal Resolution Produce More Skillful Forecasts?, B. Am. Meteorol. Soc., 83, 407-430, doi:10.1175/15200477(2002)083<0407:dihrpm>2.3.co;2, 2002.

Meehl, G. A. and Tebaldi, C.: More intense, more frequent, and longer lasting heat waves in the 21 st century, Science, 305, 994997, 2004.

Meehl, G. A., Covey, C., McAvaney, B., Latif, M., and Stouffer, R. J.: Overview of the coupled model intercomparison project, B. Am. Meteorol. Soc., 86, 89-93, doi:10.1175/bams-86-1-89, 2005.

Meehl, G. A., Covey, C., Taylor, K. E., Delworth, T., Stouffer, R. J., Latif, M., McAvaney, B., and Mitchell, J. F. B.: THE WCRP CMIP3 Multimodel Dataset: A New Era in Climate Change Research, B. Am. Meteorol. Soc., 88, 1383-1394, doi:10.1175/bams-88-9-1383, 2007.

Meehl, G. A., Washington, W. M., Arblaster, J. M., Hu, A., Teng, H., Tebaldi, C., Sanderson, B. N., Lamarque, J.-F., Conley, A., Strand, W. G., and White, J. B.: Climate system response to external forcings and climate change projections in CCSM4, J. Climate, 25, 3661-3683, doi:10.1175/jcli-d-11-00240.1, 2011.

Meinshausen, M., Smith, S. J., Calvin, K., Daniel, J. S., Kainuma, M. L. T., Lamarque, J. F., Matsumoto, K., Montzka, S. A., Raper, S. C. B., Riahi, K., Thomson, A., Velders, G. J. M., and Vuuren, D. P. P.: The RCP greenhouse gas concentrations and their extensions from 1765 to 2300, Climatic Change, 109, 213-241, doi:10.1007/s10584-011-0156-z, 2011.

Mellor, G. L. and Yamada, T.: Development of a turbulence closuremodel for geophysical fluid problems, Rev. Geophys., 20, 851875, 1982.

Morcrette, J. J., Barker, H. W., Cole, J. N. S., Iacono, M. J., and Pincus, R.: Impact of a New Radiation Package, McRad, in the ECMWF Integrated Forecasting System, Mon. Weather. Rev., 136, 4773-4798, doi:10.1175/2008mwr2363.1, 2008.

Moss, R. H., Edmonds, J. A., Hibbard, K. A., Manning, M. R., Rose, S. K., van Vuuren, D. P., Carter, T. R., Emori, S., Kainuma, M., Kram, T., Meehl, G. A., Mitchell, J. F. B., Nakicenovic, N., Riahi, K., Smith, S. J., Stouffer, R. J., Thomson, A. M., Weyant, J. P., and Wilbanks, T. J.: The next generation of scenarios for climate change research and assessment, Nature, 463, 747-756, 2010.

Nakicenovic, N. and Swart, R.: Special Report on Emissions Scenarios: A Special Report of Working Group III of the Intergovernmental Panel on Climate Change, Cambridge University Press, Cambridge, United Kingdom and New York, NY, USA, 2000. 
Neale, R. B., Richter, J. H., Conley, A. J., Park, S., Lauritzen, P. H., Gettelman, A., Williamson, D. L., Rasch, P. J., Vavrus, S. J., Taylor, M. A., Collins, W. D., Zhang, M., and Lin, S.J.: Description of the NCAR Community Atmosphere Model (CAM 4.0), NCAR Tech. Note NCAR/TN-XXX+STR (Draft), National Center for Atmospheric Research, Boulder, Colorado, 194, 2010.

Nolte, C. G., Gilliland, A. B., Hogrefe, C., and Mickley, L. J.: Linking global to regional models to assess future climate impacts on surface ozone levels in the United States, J. Geophys. Res., 113, D14307, doi:10.1029/2007jd008497, 2008.

Oleson, K. W., Lawrence, D. M., Bonan, G. B., Flanner, M. G., Kluzek, E., Lawrence, P. J., Levis, S., Swenson, S. C., Thornton, P. E., Dai, A., Decker, M., Dickinson, R., Feddema, J., Heald, C. L., Hoffman, F., Lamarque, J., Mahowald, N., Niu, G., Qian, T., Randerson, J., Running, S., Sakaguchi, K., Slater, A., Stockli, R., Wang, A., Yang, Z., Zeng, X., and Zeng, X.: Technical Description of version 4.0 of the Community Land Model (CLM), NCAR Technical Note NCAR/TN-478+STR, doi:10.5065/D6FB50WZ, 2010.

Otte, T. L. and Pleim, J. E.: The Meteorology-Chemistry Interface Processor (MCIP) for the CMAQ modeling system: updates through MCIPv3.4.1, Geosci. Model Dev., 3, 243-256, doi:10.5194/gmd-3-243-2010, 2010.

Riahi, K., Grübler, A., and Nakicenovic, N.: Scenarios of long-term socio-economic and environmental development under climate stabilization, Technological Forecasting and Social Change, 74, 887-935, doi:10.1016/j.techfore.2006.05.026, 2007.

Rogelj, J., Meinshausen, M., and Knutti, R.: Global warming under old and new scenarios using IPCC climate sensitivity range estimates, Nature Clim. Change, 2, 248-253, 2012.

Schwede, D., Pouliot, G. A., and Pierce, T.: Changes to the Biogenic Emissions Inventory System Version 3 (BEIS3), Proceedings of the 4th Annual CMAS Models-3 Users'Conference, Chapel Hill, NC, 26-28 September, 2005, online available at: http://cmascenter.org/conference/2005/abstracts/2_7.pdf, 2005.

Skamarock, W. C. and Klemp, J. B.: A time-split nonhydrostatic atmospheric model for weather research and forecasting applications, J. Comput. Phys., 227, 3465-3485, doi:10.1016/j.jcp.2007.01.037, 2008.

Smith, R., Jones, P., Briegleb, B., Bryan, F., Danabasoglu, G., Dennis, J., Dukowicz, J., Eden, C., Fox-Kemper, B., Gent, P., Hecht, M., Jayne, S., Jochum, M., Large, W., Lindsay, K., Maltrud, M., Norton, N., Peacock, S., Vertenstein, M., and Yeager, S.: The Parallel Ocean Program (POP) reference manual, Ocean Component of the Community Climate System Model (CCSM) and Community Earth System Model (CESM), Los Alamos National Laboratory Tech. Rep. LAUR-10-01853, 2010.

Smith, S. J. and Wigley, T. M. L.: Multi-Gas Forcing Stabilization with the MiniCAM, Energy Journal, (Special Issue \#3), 373-391, 2006

Solomon, S., Qin, D., Manning, M., Marquis, M., Averyt, K., Tignor, M., Miller, H. L., and Chen, Z.: IPCC 2007 Climate Change 2007: The Physical Science Basis. Contribution of Working Group I to the Fourth Assessment Report of the Intergovernmental Panel on Climate Change, Cambridge: Cambridge University Press, 2007.
Stedman, J. R.: The predicted number of air pollution related deaths in the UK during the August 2003 heatwave, Atmos. Environ., 38, 1087-1090, doi:10.1016/j.atmosenv.2003.11.011, 2004.

Stroeve, J. C., Kattsov, V., Barrett, A., Serreze, M., Pavlova, T., Holland, M., and Meier, W. N.: Trends in Arctic sea ice extent from CMIP5, CMIP3 and observations, Geophys. Res. Lett., 39, L16502, doi:10.1029/2012g1052676, 2012.

Taylor, K. E., Stouffer, R. J., and Meehl, G. A.: A Summary of the CMIP5 Experiment Design, http://www-pcmdi.llnl.gov/, 2009.

Taylor, K. E., Stouffer, R. J., and Meehl, G. A.: An Overview of CMIP5 and the Experiment Design, B. Am. Meteorol. Soc., 93, 485-498, doi:10.1175/bams-d-11-00094.1, 2012.

USEPA: Guidance on the Use of Models and Other Analyses for Demonstrating Attainment of Air Quality Goals for Ozone, PM2.5. and Regional Haze, EPA-454/B-07e002, 2007.

Vieno, M., Dore, A. J., Stevenson, D. S., Doherty, R., Heal, M. R., Reis, S., Hallsworth, S., Tarrason, L., Wind, P., Fowler, D., Simpson, D., and Sutton, M. A.: Modelling surface ozone during the 2003 heat-wave in the UK, Atmos. Chem. Phys., 10, 7963-7978, doi:10.5194/acp-10-7963-2010, 2010.

Wise, M., Calvin, K., Thomson, A., Clarke, L., Bond-Lamberty, B., Sands, R., Smith, S. J., Janetos, A., and Edmonds, J.: Implications of Limiting $\mathrm{CO}_{2}$ Concentrations for Land Use and Energy, Science, 324, 1183-1186, doi:10.1126/science.1168475, 2009.

Wong, D. C., Pleim, J., Mathur, R., Binkowski, F., Otte, T., Gilliam, R., Pouliot, G., Xiu, A., Young, J. O., and Kang, D.: WRFCMAQ two-way coupled system with aerosol feedback: software development and preliminary results, Geosci. Model Dev., 5, 299-312, doi:10.5194/gmd-5-299-2012, 2012.

Yarwood, G., Rao, S., Yocke, M., and Whitten, G.: Updates to the Carbon Bond Chemical Mechanism: CB05., U.S. Environmental Protection Agency, Research Triangle Park, NC, 2005.

Young, P. J., Archibald, A. T., Bowman, K. W., Lamarque, J.-F., Naik, V., Stevenson, D. S., Tilmes, S., Voulgarakis, A., Wild, O., Bergmann, D., Cameron-Smith, P., Cionni, I., Collins, W. J., Dalsøren, S. B., Doherty, R. M., Eyring, V., Faluvegi, G., Horowitz, L. W., Josse, B., Lee, Y. H., MacKenzie, I. A., Nagashima, T., Plummer, D. A., Righi, M., Rumbold, S. T., Skeie, R. B., Shindell, D. T., Strode, S. A., Sudo, K., Szopa, S., and Zeng, G.: Preindustrial to end 21st century projections of tropospheric ozone from the Atmospheric Chemistry and Climate Model Intercomparison Project (ACCMIP), Atmos. Chem. Phys., 13, 2063 2090, doi:10.5194/acp-13-2063-2013, 2013.

Zhang, G. J. and McFarlaneb, N. A.: Sensitivity of climate simulations to the parameterization of cumulus convection in the Canadian Climate Centre general circulation model, Atmos. Ocean, 33, 407-446, 1995.

Zhang, L., Jacob, D. J., Downey, N. V., Wood, D. A., Blewitt, D., Carouge, C. C., van Donkelaar, A., Jones, D. B. A., Murray, L. T., and Wang, Y.: Improved estimate of the policy-relevant background ozone in the United States using the GEOS-Chem global model with $1 / 2^{\circ} \times 2 / 3^{\circ}$ horizontal resolution over North America, Atmos. Environ., 45, 6769-6776, doi:10.1016/j.atmosenv.2011.07.054, 2011. 